\title{
Wind-mixing effects on feeding success and condition of blue whiting larvae in the Porcupine Bank area
}

\author{
Matthias H. F. Kloppmann*, Nicola Hillgruber**, Hein von Westernhagen \\ Alfred-Wegener-Institut für Polar- und Meeresforschung, Biologische Anstalt Helgoland, Am Handelshafen 12, \\ 27570 Bremerhaven, Germany
}

\begin{abstract}
Prey environment, feeding success and condition of blue whiting Micromesistius poutassou larvae were analysed in contrasting meteorological situations west of Ireland in the spring of 2 consecutive years (1994 and 1995). While larval abundance in both years of the study was approximately equal, there were marked differences in the physical and biological environment between the 2 years. 1994 was characterised by strong, unidirectional wind stress, which probably caused the low overall abundance of prey organisms recorded in this year. Abundance of copepod eggs and nauplii was considerably higher in 1995, when wind speeds were lower and wind direction was more variable. Copepod nauplii were also significantly larger than in 1994. Larval feeding success in both years was highly variable, but with considerably higher feeding intensities in 1995 than in 1994. For the determination of larval condition, 3 different condition indices were used, Fulton's $K$ index (FCI) and body height to body length ratio for between-year comparison, and carbon and nitrogen content for estimation of immediate effects of wind stress on larval condition. In 1994, the FCI of blue whiting larvae was significantly lower than in 1995, and $11 \%$ of the larvae were significantly lighter at length than their conspecifics, suggesting that a part $(11 \%)$ of the larval population at any one time fed less successfully at low prey density and high turbulence levels. No differences between the years were observed using the index of body height at the anus versus standard length. Analyses of relative $\mathrm{C}$ and $\mathrm{N}$ content of blue whiting larvae in relation to varying wind stress showed that while wind stress had a minor negative effect on $\mathrm{C}$ content, relative $\mathrm{N}$ content was significantly reduced with increasing wind speed, indicating that at periods of high wind-mixing more protein is catabolised in order to satisfy increasing energy demands, thus leaving less material to be assimilated for growth.
\end{abstract}

KEY WORDS: Blue whiting $\cdot$ Fish larvae $\cdot$ Condition $\cdot$ Wind-mixing $\cdot$ Carbon and nitrogen content Resale or republication not permitted without written consent of the publisher

\section{INTRODUCTION}

Temporal or spatial match or mismatch of fish larvae with their potential prey organisms (e.g. Lasker 1975, Cushing 1990) is considered to be one of the major factors regulating year-class strength in marine fish populations. While adequate numerical abundance of

Present addresses:

${ }^{*}$ Institut für Hydrobiologie und Fischereiwissenschaft, Olbersweg 24, 22767 Hamburg, Germany.

E-mail: kloppmannmh@hansenet.de

** Juneau Center, School of Fisheries and Ocean Studies, University of Alaska Fairbanks, 11120 Glacier Highway, Juneau, Alaska 99801, USA potential prey organisms alone often has failed to support a corresponding high survival of fish larvae, adequate microscale turbulence has appeared to be necessary to generate a positive effect on the availability of food organisms to planktonic predators (Rothschild \& Osborn 1988). Over the last decade, considerable work has been published supporting this theory to various degrees (e.g. Sundby \& Fossum 1990, Kiørboe \& Saiz 1995, Sundby 1995, Dower et al. 1997 and literature therein). Several studies have indicated that the relationship between turbulence, successful feeding, survival, and subsequent recruitment is in most cases non-linear (e.g. Cury \& Roy 1989, MacKenzie et al. 1994, Leising \& Franks 1999), suggesting that benefi- 
cial effects of turbulence only occur at intermediate levels, while at higher levels the speed of the predator relative to its prey might be too fast for a successful capture (Fiksen et al. 1998, MacKenzie \& Kiørboe 2000).

Strong wind-mixing can have a multitude of effects that might in turn influence survival of larval blue whiting. Wind-mixing is known to (e.g.) disrupt layers of high prey concentrations (Lasker 1975) and reduce the efficiency of energy transfer from phytoplankton production to higher trophic levels (Lewis et al. 1994).

The waters west of the British Isles comprise the major spawning area of blue whiting (Bailey 1982, Isaev \& Seliverstov 1991) at a time (March \& April) when the risk of strong wind-mixing is relatively high (DHI 1967). Low prey density at the time of high blue whiting larval abundance (Hillgruber et al. 1997, Hillgruber \& Kloppmann 1999) might imply that, in order to survive, the larvae have to benefit from enhanced encounter rates associated with wind-induced turbulence. However, Hillgruber \& Kloppmann (2000) found that feeding at moderate wind speeds, slightly higher than $10 \mathrm{~m} \mathrm{~s}^{-1}$, was significantly reduced compared to almost calm situations. These results suggest that in years of high storm activities, particularly around the early larval phase, blue whiting survival might be poor due to turbulence-induced malnutrition.

1994 and 1995 were characterised by contrasting wind situations at the time of high abundance of larval blue whiting. Particularly during the early larval stage of blue whiting in March and April, relatively strong westerly to south-westerly winds prevailed in 1994, while wind stress was much lower and of high directional variability in 1995 (Bartsch \& Coombs 1997). Even though both years were characterised by equally high blue whiting egg and larval abundances west of the British Isles (SEFOS 1997, Kloppmann et al. 2001, S. Coombs, Marine Biological Association of the

Table 1. Micromesistius poutassou. Summary of survey information on cruises of RV 'Heincke' for 1994 (H56) and 1995 (H67)

\begin{tabular}{|lcc|}
\hline & 1994 & 1995 \\
\hline Dates of sampling & March 25-27, & April 5-7 \\
& April 6, 8 & \\
Number of stations & 13 & 17 \\
Samples per stations & 3 & 5 \\
Depth profile (m) & $100-50$, & $100-80$, \\
& $50-25,25-0$ & $80-60$, \\
& & $60-40$, \\
No. of feeding samples & 633 & $40-20,20-0$ \\
Size range (mm) & $2.5-8.3$ & 1640 \\
Feeding larvae (\%) & 79.6 & $2.0-7.0$ \\
& & 83.8 \\
\hline
\end{tabular}

United Kingdom, pers. comm.), recruitment success differed significantly (Anonymous 1996). In 1994, blue whiting recruitment was slightly below the long-term mean, while recruitment in 1995 was (at that time) the highest on record (Anonymous 1996). Similar observations were made for larval walleye pollock Theragra chalcogramma in Shelikof Strait, Alaska, namely an association of strong wind-mixing events in the firstfeeding larval period with lower recruitment and a linking of calm wind situations with strong survival periods (Bailey \& Macklin 1994). Thus, it appears that the higher blue whiting recruitment success in 1995 might be the result of the lower wind-mixing in that year, either translating to higher prey concentrations and, thus, better feeding success, or improving the availability of prey organisms due to reduced windgenerated turbulence. Both mechanisms would result in better larval condition and, thus, could enhance survival through the first critical period of early life.

In this paper we investigate prey field, feeding success and condition of blue whiting larvae in relation to differing wind-mixing patterns during the period of first-feeding. Based on these comparisons we attempt to test the hypothesis that there is a causal relationship between wind stress and survival of blue whiting larvae via food availability.

\section{MATERIALS AND METHODS}

Shipboard sampling. During 2 cruises with RV 'Heincke' in March/April 1994 and April 1995 (Table 1) to the west of Ireland, blue whiting Micromesistius poutassou larvae were sampled with a towed HydroBios multiple-opening-closing-net ( $\mathrm{MCN})$ with a $50 \times 50 \mathrm{~cm}$ opening and 150 (1994) to $200 \mu \mathrm{m}$ (1995) mesh. The smaller mesh size in 1994 was chosen to efficiently catch the recently hatched and non-feeding larvae which predominantly occur at depths $>100 \mathrm{~m}$ (Kloppmann et al. 2001). While in 1994 sampling was done on a large-scale station grid in waters above the Irish Shelf and Porcupine Bank to a maximum depth of $650 \mathrm{~m}$, all samples in 1995 were taken from tows to a maximum depth of $100 \mathrm{~m}$ during a drift study carried out above the western slope of Porcupine Bank (Fig. 1). A bias in the feeding and condition-index results due to different sampling designs in both years is ruled out because all 1994 feeding and condition-index samples were from a rather restricted area where blue whiting larvae were very abundant (Fig 1: encircled area; and Kloppmann et al. 2001). The 1995 study was carried out almost in the centre of this area. Because this study exclusively deals with feeding of blue whiting larvae $>3.0 \mathrm{~mm}$ occurring in the top $100 \mathrm{~m}$ (Kloppmann et al. 2001), no mesh size- and catch-depth-related dif- 
ferences in catch efficiency with respect to length is anticipated.

All plankton samples were preserved immediately after collection in buffered $4 \%$ formaldehyde-seawater solution. Ichthyoplankton sampling was accompanied by routine measurements of physical data, such as temperature and salinity down the water column with a conductivity temperature depth probe (CTD). Water bottle samples were taken at 5 depths to determine abundance and composition of potential prey organisms. Wind speed was measured by an anemometer mounted on the mast of the ship and recorded every half hour. Detailed descriptions of all sampling procedures and the respective results are given in Hillgruber \& Kloppmann $(1999,2000)$ and Kloppmann et al. (2001).

In addition to the MCN hauls in 1995, double oblique tows with a $60 \mathrm{~cm}$ Bongo net equipped with $200 \mu \mathrm{m}$ mesh nets were conducted at each station to obtain blue whiting larvae for carbon and nitrogen content analysis (see 'Condition analysis' below). Hauls were carried out down to $40 \mathrm{~m}$ depth in order to reduce sampling time and, thus, assure minimum damage to the larvae. Since most blue whiting larvae occurred within the top $40 \mathrm{~m}$ (Hillgruber \& Kloppmann 2000), the representative nature of the sampling can be assumed. Immediately after recovery of the Bongo net, cod-end buckets were detached and transferred to a constant temperature $\left(10^{\circ} \mathrm{C}\right)$ laboratory on board RV 'Heincke'. Cod-end buckets were emptied into a sorting dish placed on a bed of crushed ice to avoid instant deterioration of the larvae. Blue whiting larvae were sorted, measured to the nearest $1.0 \mathrm{~mm}$ standard length (SL) and triple-washed in distilled water. To meet the minimum dry wt requirements for analysis precision of the Heraeus CHN analysing system, a minimum of 5 to 15 larvae, depending on size, were pooled and deepfrozen at $-35^{\circ} \mathrm{C}$ in pre-weighed tin capsules.

Laboratory analyses. In the laboratory, ichthyo- and microzooplankton samples as well as blue whiting larval gut contents were analysed according to standard analysing methods. Details are given in Hillgruber \& Kloppmann $(1999,2000)$. Preserved blue whiting larvae were randomly selected from MCN samples of the 1994 and 1995 cruises to determine between-year differences in condition. For each individual larva the standard length and myotome body height above the anus (to the nearest $0.1 \mathrm{~mm}$ ) was measured and the dry wt was determined after freeze-drying these larvae.

Condition analysis. Altogether, 3 different condition indices were determined for the comparative study: 2 morphometric indices and 1 biochemical index. Morphometric indices are generally derived by using a variable that is relatively sensitive to starvation and adjusting it with a starvation-insensitive variable like length to remove the effect of body size (Koslow et al.
1985, Suthers et al. 1992). The first morphometric index, Fulton's condition index (FCI), is defined as

$$
\mathrm{FCI}=\frac{\mathrm{DW} \times 100}{\mathrm{SL}^{3}}
$$

where DW is dry wt and SL is standard length (Frank \& McRuer 1989). FCI represents an isometric index that could potentially covary with length and, thus, prevent comparison of condition between different-sized larvae (Koslow et al. 1985). However, since we were comparing between-year differences in FCI of larvae of comparable size ranges, a potential co-variation of FCI with size will not alter the meaning of results.

The second morphometric index utilised was the relationship of body height above the anus over standard length. In a comparison of different morphometric indices, this index proved most sensitive to environmental conditions (Koslow et al. 1985). In addition to comparisons of between-year differences in mean condition indices, we also conducted multiple regression analysis (Chambers \& Hastie 1992, MathSoft 1999) to examine the influence of standard length and year as well as the interaction of both on dry wt and body height.

Both morphometric indices were estimated with formaldehyde-preserved larvae. Formaldehyde is known to dissolve lipids from tissues and, therefore, dry wt measurements may have been influenced by this fact. However, the lipid content of young fish larvae is considered to be low, highly variable, and not necessarily linked to nutritional condition (Ferron \& Leggett 1994). We therefore consider the resulting bias to be negligible.

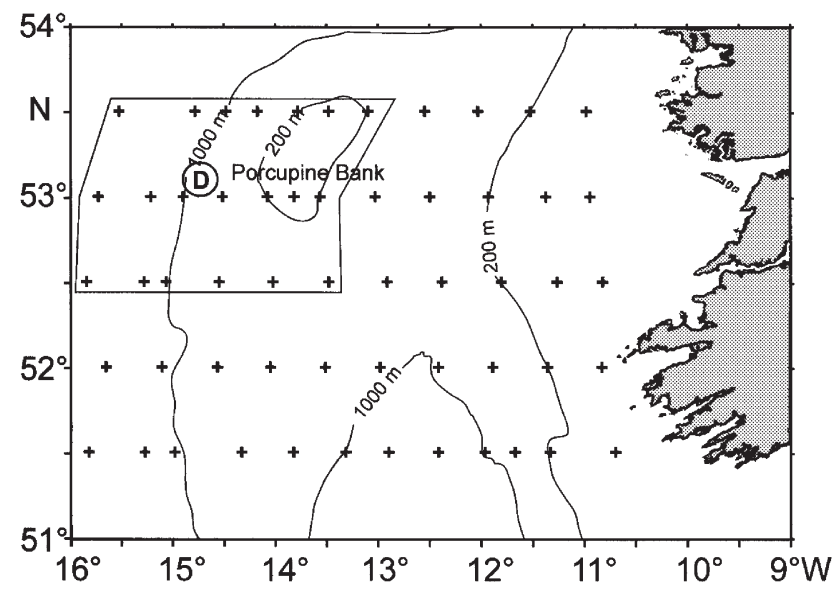

Fig. 1. Map of the study area indicating 1994 sampling stations and site of the drift study (D) in 1995. Encircled area represents the 1994 samples from which Micromesistius poutassou larvae were selected for stomach content and morphometric condition analysis 
Table 2. Mean density of microzooplankton groups $\left(\mathrm{l}^{-1}\right)$ in the upper $100 \mathrm{~m}$ water column above Porcupine Bank in 1994 and 1995. Mean densities were calculated using square-root $(x+0.5)$ transformed variates. ns: non-significant

\begin{tabular}{|lccc|}
\hline Taxa & 1994 & 1995 & $\mathrm{p}$ \\
\hline Copepod eggs & 0.19 & 0.63 & 0.001 \\
Copepod nauplii & 5.99 & 19.09 & 0.001 \\
Copepodites and & 3.03 & 3.14 & $\mathrm{~ns}$ \\
adult copepods & & & \\
\hline
\end{tabular}

To test the immediate effect of wind stress on larval condition, a third index, the proportionate amount of $\mathrm{C}$ and $N$, was measured for blue whiting larvae caught during the continuous-patch study in 1995, providing also the $\mathrm{C} / \mathrm{N}$ ratio as an index of condition. While the $\mathrm{C} / \mathrm{N}$ ratio is often used as a condition index in fish larvae (Ehrlich 1974a,b, von Westernhagen et al. 1998 and literature therein), its value is questionable because of the complex and often correlated behaviour of carbon and nitrogen content in relation to individual physiology (Ferron \& Leggett 1994). However, treated on their own, $\mathrm{C}$ and $\mathrm{N}$ content can give valuable insights into the in situ condition of fish larvae (Christensen \& Korsgaard 1999, Coombs et al. 1999). Blue whiting larvae that were deep-frozen in pre-weighed tin capsules on board the RV 'Heincke' were freezedried in the laboratory and their dry wt determined; they were then processed in a Heraeus CHN analyser. Acetanilide was used as the calibration agent. The effects of wind stress, time of day and individual mean dry wt plus their interaction on carbon and nitrogen content in blue whiting larvae was examined using multiple regression with routines of S-Plus software (Chambers \& Hastie 1992, MathSoft 1999). Wind values were averaged over $6 \mathrm{~h}$ prior to sampling. Since none of the interaction terms showed any significant influence on both $\mathrm{C}$ and $\mathrm{N}$ content, these terms were dropped from the final linear models.

\section{RESULTS}

\section{Physical environment}

Temperature and salinity of the water column were quite similar in both 1994 and 1995 (White et al. 1998, Kloppmann et al. 2001). Temperatures in the top $100 \mathrm{~m}$ ranged between 10.2 and $10.3^{\circ} \mathrm{C}$, with salinity values slightly $>35.4$. The water column was homogeneously mixed and no seasonal stratification was discernible.

In contrast, the wind situation differed conspicuously between both years. In 1994, relatively strong and unidirectional winds, mainly from the west to south-west, prevailed (Bartsch \& Coombs 1997). Frequent storms resulted in deep mixing of the water column and a

Table 3. Micromesistius poutassou. \% (by number) prey items ingested by larvae in 1994 and 1995

\begin{tabular}{|c|c|c|c|c|c|c|}
\hline Prey items & $<3.0 \mathrm{~mm}$ & $3.0-3.9 \mathrm{~mm}$ & $4.0-4.9 \mathrm{~mm}$ & $5.0-5.9 \mathrm{~mm}$ & $\geq 6.0 \mathrm{~mm}$ & Total \\
\hline \multicolumn{7}{|l|}{1994} \\
\hline Tintinnids & 44.0 & 16.5 & 2.1 & 0.0 & 0.0 & 15.6 \\
\hline Eggs & 5.8 & 11.4 & 16.8 & 13.5 & 5.3 & 11.4 \\
\hline Cyclopoid nauplii & 31.3 & 39.1 & 24.1 & 6.5 & 6.0 & 29.7 \\
\hline Harpacticoid nauplii & 0.0 & 0.2 & 0.0 & 0.0 & 0.0 & 0.1 \\
\hline Calanoid nauplii & 10.6 & 21.9 & 41.9 & 53.6 & 37.1 & 27.9 \\
\hline Other nauplii & 4.1 & 3.7 & 3.2 & 1.5 & 13.7 & 4.1 \\
\hline Copepodites & 1.3 & 4.0 & 10.2 & 15.4 & 31.7 & 7.5 \\
\hline Adults & 0.1 & 0.2 & 1.0 & 6.9 & 1.5 & 1.0 \\
\hline Others & 2.8 & 3.2 & 0.7 & 2.5 & 4.7 & 2.6 \\
\hline Number of larvae & 85 & 237 & 107 & 44 & 31 & 504 \\
\hline \multicolumn{7}{|l|}{1995} \\
\hline Tintinnids & 37.9 & 10.3 & 5.5 & 2.8 & 0.0 & 11.3 \\
\hline Eggs & 18.3 & 30.6 & 30.8 & 34.5 & 33.8 & 29.5 \\
\hline Cyclopoid nauplii & 14.4 & 32.2 & 40.0 & 34.2 & 17.6 & 32.7 \\
\hline Harpacticoid nauplii & 1.0 & 0.4 & 0.3 & 0.2 & 0.0 & 0.4 \\
\hline Calanoid nauplii & 7.8 & 7.5 & 6.3 & 5.7 & 4.0 & 6.9 \\
\hline Other nauplii & 2.1 & 5.3 & 5.9 & 5.4 & 12.8 & 5.2 \\
\hline Copepodites & 0.0 & 0.7 & 3.1 & 8.8 & 13.9 & 2.4 \\
\hline Adults & 0.0 & 0.0 & 1.9 & 4.7 & 13.7 & 1.3 \\
\hline Others & 18.4 & 13.1 & 6.2 & 3.8 & 4.2 & 10.3 \\
\hline Number of larvae & 182 & 539 & 498 & 141 & 15 & 1375 \\
\hline
\end{tabular}


breakdown of the anti-cyclonic circulation system above Porcupine Bank (Mohn 2000, Kloppmann et al. 2001). In 1995, moderate winds, which were very variable in direction, prevailed (Bartsch \& Coombs 1997).

During the 1994 cruise, average wind speed was $14.9 \mathrm{~ms}^{-1}$ with maximum values up to $27.9 \mathrm{~ms}^{-1}(\mathrm{SD}=4.8$, median $=14.8$, range: 2.1 to $27.9, \mathrm{n}=759$ ). In contrast, wind speeds during the 1995 cruise were much lower, with an average speed of $8.6 \mathrm{~ms}^{-1}$ and maximum values only up to $15.1 \mathrm{~ms}^{-1}(\mathrm{SD}=3.5$, median $=9.0$, range: 0.5 to $15.1, \mathrm{n}=151$ ).

\section{Prey environment}

In March-April 1994, the densities of potential prey organisms for blue whiting larvae were substantially lower than at the same time in 1995. Specifically, copepod eggs and copepod nauplii in the upper $100 \mathrm{~m}$ of the water column were significantly more abundant in 1995 (Table 2). The highest differences in abundance of microzooplankton taxa were observed for copepod nauplii, the primary prey item of blue whiting larvae (Conway 1980, Hillgruber et al. 1997, Hillgruber \& Kloppmann 1999).

The vertical distribution of copepod nauplii differed significantly in the 2 years of the study, with nauplii being randomly distributed in the upper $100 \mathrm{~m}$ in 1994. In comparison, depth had a significant effect on naupliar distribution in 1995, with peak densities at $30 \mathrm{~m}$ depth. Densities of copepod nauplii above and below $30 \mathrm{~m}$ were significantly lower (ANOVA, $F=19.352, \mathrm{p}<0.001$ ).

Sizes of copepod nauplii ranged from 50 to $500 \mu \mathrm{m}$ total length (TL) in 1994 and from 60 to $680 \mu \mathrm{m}$ in 1995, and size-frequency distributions revealed significant differences between the 2 years (Kolmogorov-Smirnov [KS] test: $\mathrm{p}<0.001)$, with significantly different means $(T=7.772, p<0.001)$. Copepod nauplii in the water column were larger in 1995, with a mean TL of $167.40 \mu \mathrm{m}$ in comparison to a mean TL of $146.87 \mu \mathrm{m}$ in 1994. Differences in naupliar TL was mainly due to a lower proportion of smaller cyclopoid nauplii in 1994. Among the copepod nauplii, 1995 was characterised by proportionately more calanoid nauplii, such as Calanus sp., Microcalanus sp. and Metrididae.

\section{Feeding success}

A total of 633 (range: 2.5 to $8.3 \mathrm{~mm} \mathrm{SL)} \mathrm{and} 1640$ (range: 2.0 to $7.0 \mathrm{~mm} \mathrm{SL}$ ) blue whiting larvae in 1994 and 1995, respectively, were analysed for their feeding

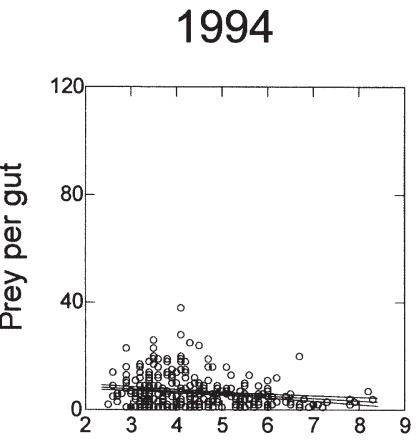

1995

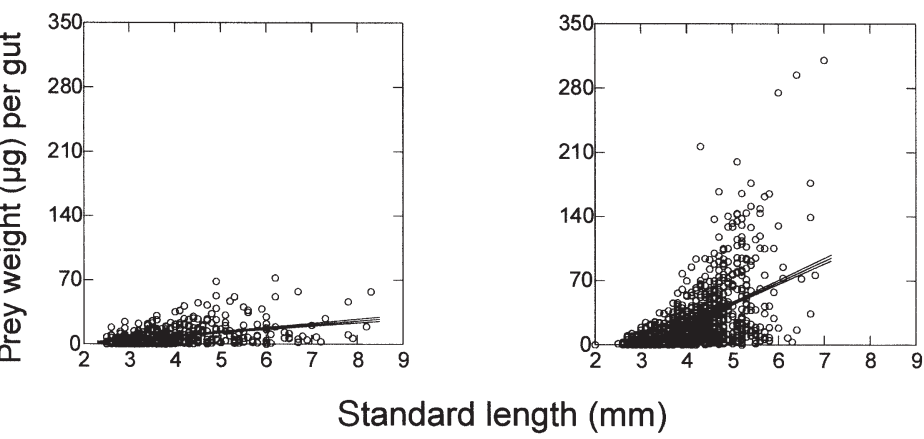

Fig. 2. Micromesistius poutassou. Numerical feeding intensities of larvae in 1994 and 1995

patterns (Table 1). Averaged over all sizes and sampling times, the proportion of feeding larvae did not differ significantly between 1994 and 1995, namely 79.6 and $83.8 \%$, respectively.

In both years, the feeding incidence was lowest for first-feeding individuals, but increased thereafter. Numerical feeding intensity (i.e. the number of prey items per larval gut), however, differed for larvae in 1994 and in 1995 (Fig. 2). In 1994, highest numbers of prey items were observed in first-feeding larvae, with numerical feeding intensity decreasing thereafter $(y=-0.8883 x+$ $\left.10.508, \mathrm{r}^{2}=0.0304, \mathrm{p}<0.001\right)$. In comparison, numerical feeding intensity steadily increased with increasing larval length in $1995\left(y=8.2115 x-18.984, r^{2}=0.0937\right.$, $\mathrm{p}<0.001$ ). In 1994, in spite of the contrasting pattern in numerical feeding intensities, weight-based intensities increased with increasing larval size $(y=3.3248 x-$ $\left.2.53, \mathrm{r}^{2}=0.0937, \mathrm{p}<0.001\right)$. While the same was true for weight-based feeding intensities in 1995, however, the increase with larval size was distinctly steeper $\left(y=23.04 x-69.883, \mathrm{r}^{2}=0.3576, \mathrm{p}<0.001\right)$.

An analysis of the composition of the larval diet revealed distinct differences between the 2 years of our study. In 1994, first-feeding larvae <4.0 mm relied most heavily on tintinnids and cyclopoid nauplii, while in 1995 there was a high proportion of copepod eggs in their diet (Tables $3 \& 4$ ). This was apparent in both the 
Table 4. Micromesistius poutassou. \% (by weight) prey items ingested by larvae in 1994 and 1995

\begin{tabular}{|c|c|c|c|c|c|c|}
\hline Prey items & $<3.0 \mathrm{~mm}$ & $3.0-3.9 \mathrm{~mm}$ & $4.0-4.9 \mathrm{~mm}$ & $5.0-5.9 \mathrm{~mm}$ & $\geq 6.0 \mathrm{~mm}$ & Tota \\
\hline \multicolumn{7}{|l|}{1994} \\
\hline Tintinnids & 21.8 & 6.2 & 0.2 & 0.0 & 0.0 & 6.6 \\
\hline Eggs & 10.6 & 16.5 & 16.8 & 11.9 & 2.8 & 14.3 \\
\hline Cyclopoid nauplii & 46.1 & 38.9 & 18.2 & 3.4 & 2.8 & 30.3 \\
\hline Harpacticoid nauplii & 0.0 & 0.1 & 0.0 & 0.0 & 0.0 & 0.0 \\
\hline Calanoid nauplii & 12.5 & 25.0 & 41.0 & 51.2 & 28.5 & 28.8 \\
\hline Other nauplii & 4.4 & 4.4 & 2.7 & 1.1 & 12.5 & 4.3 \\
\hline Copepodites & 3.4 & 5.8 & 17.9 & 21.1 & 41.6 & 11.6 \\
\hline Adults & 0.4 & 0.8 & 2.9 & 10.3 & 5.0 & 2.3 \\
\hline Others & 0.8 & 2.4 & 0.2 & 1.0 & 6.8 & 1.8 \\
\hline Number of larvae & 84 & 237 & 107 & 44 & 32 & 504 \\
\hline \multicolumn{7}{|l|}{1995} \\
\hline Tintinnids & 32.4 & 6.1 & 1.2 & 0.6 & 0.0 & 7.1 \\
\hline Eggs & 32.4 & 46.1 & 43.4 & 35.1 & 18.7 & 41.9 \\
\hline Cyclopoid nauplii & 16.8 & 31.9 & 32.3 & 22.5 & 6.3 & 28.8 \\
\hline Harpacticoid nauplii & 1.3 & 0.3 & 0.1 & 0.0 & 0.0 & 0.3 \\
\hline Calanoid nauplii & 6.7 & 5.8 & 2.9 & 2.9 & 1.7 & 4.5 \\
\hline Other nauplii & 1.8 & 4.4 & 3.9 & 3.3 & 18.6 & 3.9 \\
\hline Copepodites & 0.0 & 1.2 & 7.3 & 17.3 & 18.3 & 5.1 \\
\hline Adults & 0.0 & 0.2 & 8.5 & 16.0 & 30.1 & 5.1 \\
\hline Others & 8.6 & 4.0 & 0.6 & 2.3 & 6.2 & 3.2 \\
\hline Number of larvae & 182 & 538 & 498 & 141 & 15 & 1374 \\
\hline
\end{tabular}

numerical and the weight-based proportion of prey items. Later-stage larvae in 1994 shifted feeding towards the larger calanoid nauplii and copepodite stages. In comparison, in 1995, larvae of all size classes analysed continued to prey on cyclopoid nauplii and copepod eggs. While they did include copepodite stages and adult copepods in their diet, proportions rarely reached the values observed in 1994.

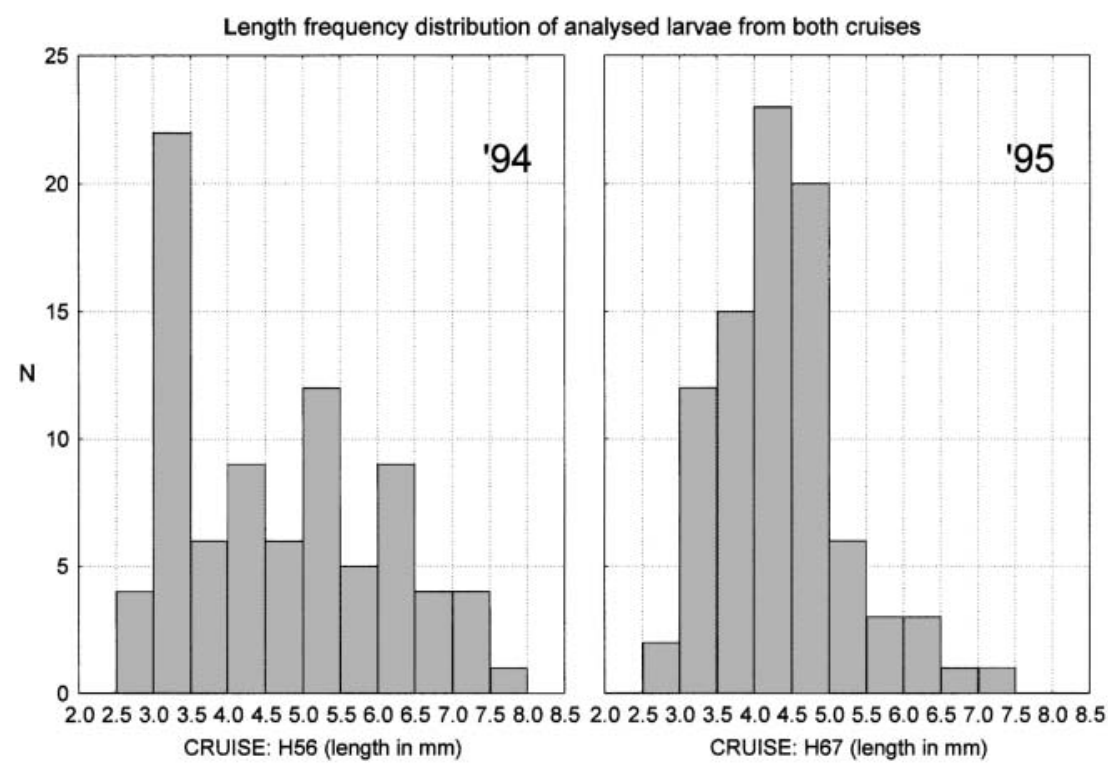

Fig. 3. Micromesistius poutassou. Length frequency distribution of larvae selected for morphometric condition analysis

\section{Comparison of 1994 and 1995 morphometric condition factors}

A total of 168 formaldehyde-preserved blue whiting larvae (1994: 82 larvae, 1995: 86 larvae) were randomly selected, measured, freeze-dried and weighed. Even though larvae from the 1994 samples covered a wider length range (2.7 to $7.9 \mathrm{~mm}$ ) than those from the 1995 samples (3.0 to $7.1 \mathrm{~mm})$, the difference in mean lengths (1994: mean $=4.694, \mathrm{SD}=1.378$; 1995: mean $=4.437, \mathrm{SD}=0.844)$ was not significant (Student's $t$-test: $t=$ 1.4664, df $=166, \mathrm{p}=0.144)$. Lengthfrequency distribution of both larval samples revealed conspicuous differences (Fig. 3). While the 1994 histogram showed a distinct mode in the 3.0 to $3.5 \mathrm{~mm}$ length class and an almost equal distribution over the remaining length range, the 1995 histogram revealed a mode in the 4.0 to $4.5 \mathrm{~mm}$ length class, with the majority of the larvae being $<5.0 \mathrm{~mm}$ in size. Thus, while more larvae of intermediate length were analysed from the 1995 samples, proportionately more small and large larvae were weighed and measured from the 1994 samples. 
Table 5. Micromesistius poutassou. Morphological condition indices for cruises H56 and H67 larvae. FCI: Fultons's condition index; Body h/L ratio: body height/length ratio

\begin{tabular}{|lcc|}
\hline Index & H56 & H67 \\
\hline FCI & & \\
Mean & 0.0964 & 0.1151 \\
SD & 0.0290 & 0.0232 \\
Median & 0.0928 & 0.1100 \\
Range & $0.0288-0.1712$ & $0.0746-0.1855$ \\
Body h/L ratio & & \\
Mean & 0.0852 & 0.0893 \\
SD & 0.0155 & 0.0097 \\
Median & 0.0839 & 0.0899 \\
Range & $0.0566-0.1216$ & $0.0588-0.1129$ \\
Number of larvae & 82 & 86 \\
\hline
\end{tabular}

\section{Larval dry wt and Fulton's condition index}

The dry wt of the 1994 formaldehyde-preserved blue whiting larvae ranged between 13 and $439 \mu \mathrm{g}$ (mean = $116.2 \mu \mathrm{g}, \mathrm{SD}=102.5 \mu \mathrm{g}$ ), while in 1995 formaldehydepreserved larvae weighed between 30 and $498 \mu \mathrm{g}$ $($ mean $=110.9, \mathrm{SD}=73.6 \mu \mathrm{g})$. For both cruises, dry wt significantly increased with increasing length, and the resulting regression equations were:

1994: $\mathrm{DW}=0.0018 \times \mathrm{SL}^{2.5484}, \mathrm{r}^{2}=0.8484, \mathrm{p} \ll 0.001$ 1995: $\mathrm{DW}=0.0013 \times \mathrm{SL}^{2.9041}, \mathrm{r}^{2}=0.8914, \mathrm{p} \ll 0.001$

where DW = dry wt in mg and SL = standard length in $\mathrm{mm}$ (Fig. 4). There was a conspicuous difference between both regression coefficients, and Fulton's condition index was significantly higher for 1995 blue whiting larvae than for the 1994 individuals (Table 5; $\delta=0.0187$; Student's $t$-test: $t=-4.620$, df $=166, \mathrm{p} \ll$ 0.0001). However, while for 1995 larvae there was no significant relationship between length and FCI $\left(\mathrm{r}^{2}=\right.$ $0.0062, \mathrm{p}=0.4700$ ), in 1994 larvae FCI decreased significantly with increasing length, indicating that, in contrast to 1995, the larvae were not growing isometrically. The regression equation for 1994 was:

$$
\mathrm{FCI}=0.1371-0.0087 \times \mathrm{SL}, \mathrm{r}^{2}=0.1697, \mathrm{p}<0.001
$$

where FCI = Fulton's condition index in 1994 and SL = standard length in $\mathrm{mm}$.

The distribution of the variates around the 1994 length to dry wt regression curve suggests that the lower regression coefficient in 1994 was caused by an $11 \%$ proportion of poorly conditioned larvae (i.e. 9 individuals with comparatively low dry wt; Fig. 4a: data enclosed by dashed line). These larvae were from different stations, so that a spatial effect could be ruled out. Indeed, without these values the regression coefficient of the 1994 values increased to $\beta=2.6891$ (Fig. 4a: dashed curve).
To analyse the effect of standard length, year and the interaction of both on dry wt, we conducted multiple regression analyses with all data, a data set without the above-mentioned 'poor' variates, and a data set consisting of the 'poor' variates only (for the 1994 data). The resulting models revealed that in all 3 tests, standard length had the strongest effect on dry wt, explaining 84.1, 91.3 and $65.4 \%$, respectively, of the total variability in dry wt. Within the first 2 set-ups, i.e. full data set and the data set without 'poor' variates, year and interaction of year with standard length had no significant influence on dry wt. However, sampling year had a significant effect $(\mathrm{p}=0.0143$ ) on dry wt for the 1994 data set consisting of 'poor' variates only, for which it explained $24.3 \%$ of total dry wt variability, suggesting that $11 \%$ of the 1994 blue whiting larvae were significantly lighter than their conspecifics.

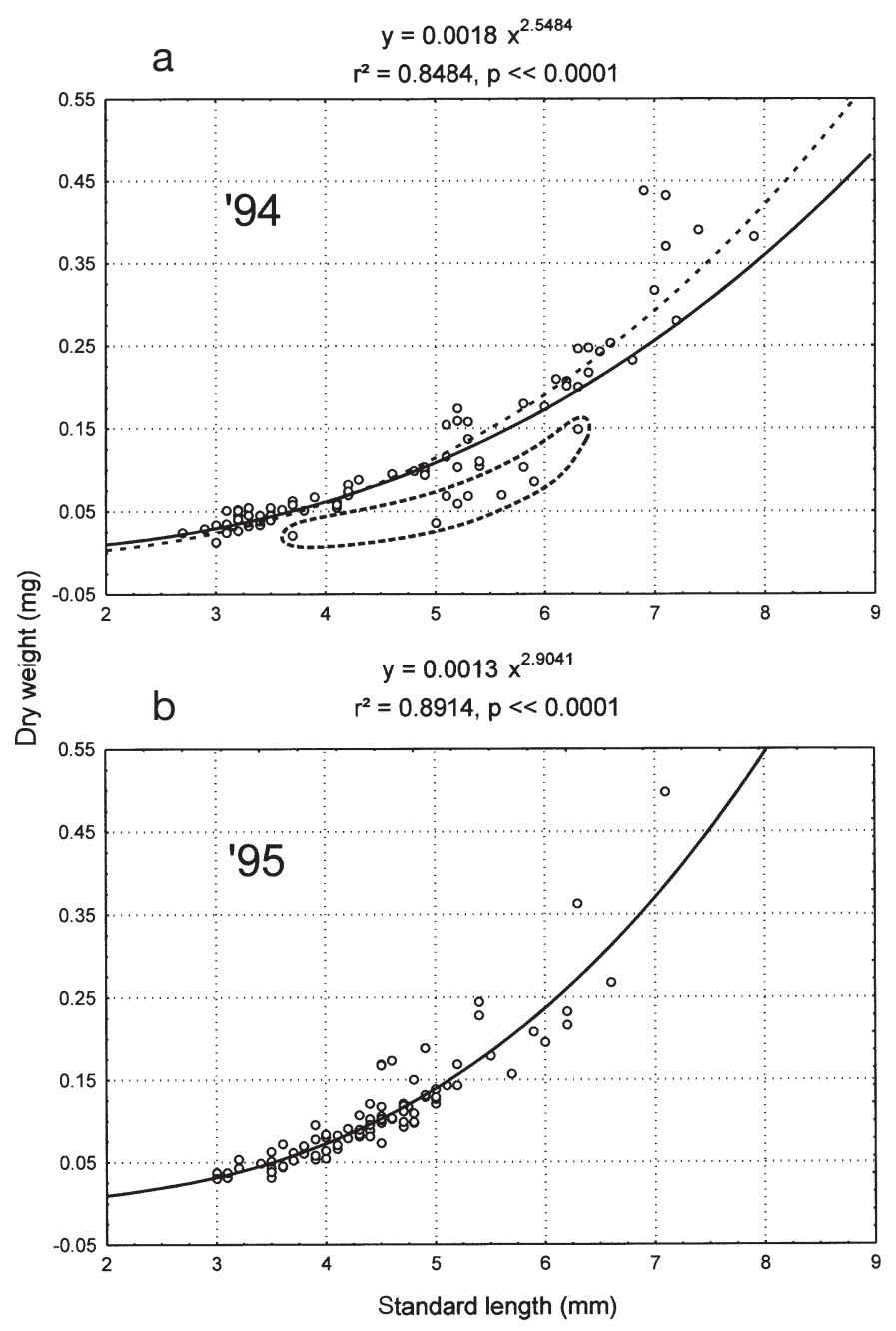

Fig. 4. Micromesistius poutassou. Standard length to dry wt relation in larvae in 1994 (upper graph) and in 1995 (lower graph). Continuous line: regression curve for length/dry wt relationship; dashed line in upper graph: regression curve estimated without encircled data 

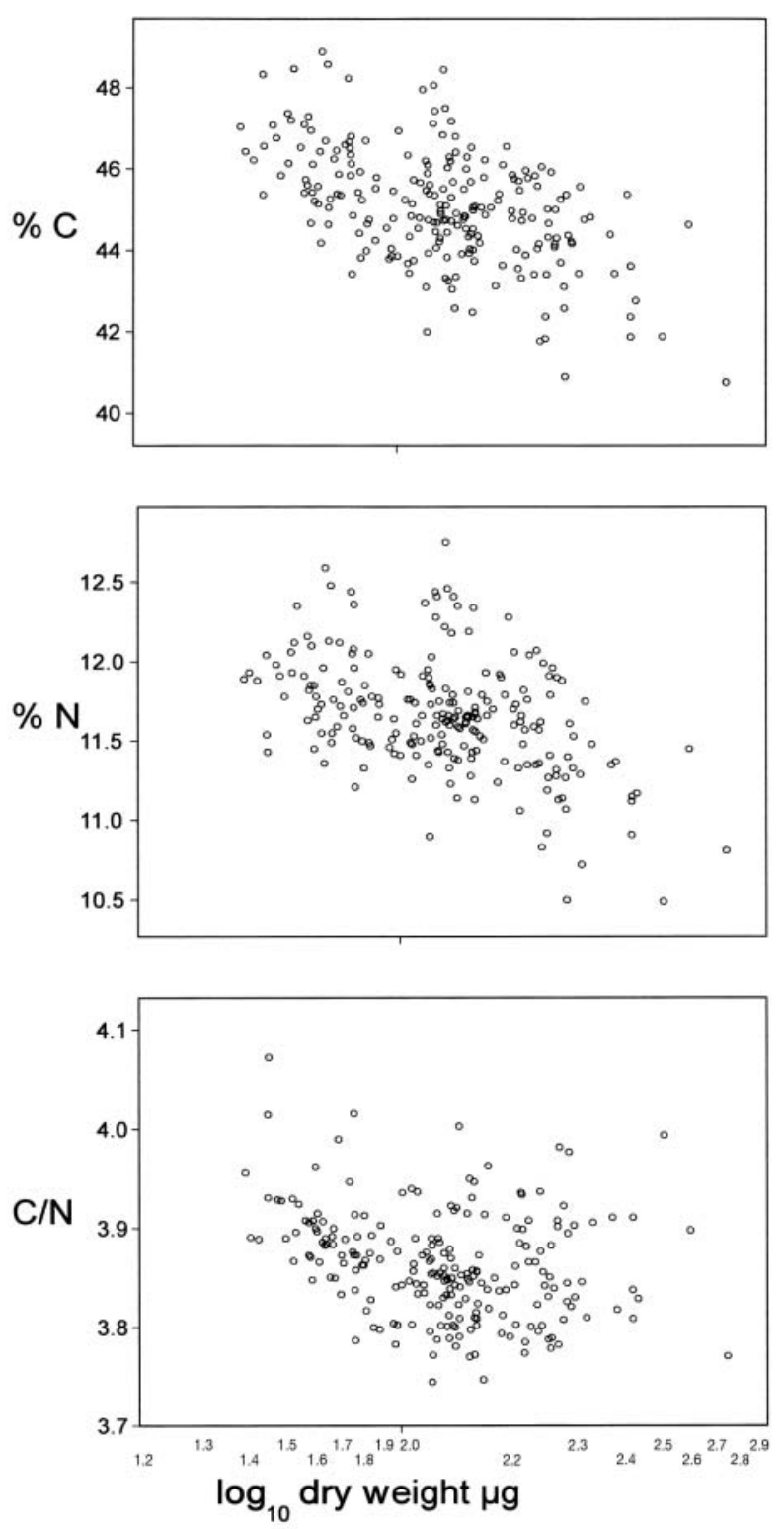

Fig. 5. Micromesistius poutassou. Scatterplots for relationship of $\log _{10}$ dry wt to $\mathrm{C}, \mathrm{N}$, and $\mathrm{CN}$ ratio

Thus, FCI and the length to dry wt relationship revealed that in 1994 blue whiting larvae had a significantly poorer condition than those in 1995.

\section{Body height-standard length relationship}

Body height above the anus increased significantly and linearly with increasing length on both cruises. The resulting regression equations are:

1994: $\mathrm{AH}=0.133+0.116 \times \mathrm{SL}, \mathrm{r}^{2}=0.8526, \mathrm{p} \ll 0.0001$ 1995: $\mathrm{AH}=0.107+0.114 \times \mathrm{SL}, \mathrm{r}^{2}=0.7931, \mathrm{p} \ll 0.0001$ where $\mathrm{AH}=$ body height above anus in $\mathrm{mm}, \mathrm{SL}=$ standard length in $\mathrm{mm}$. These equations indicate an almost identical body height to length relationship for both years. Indeed, correlation coefficients for both years did not differ significantly ( $t=-0.2207, \mathrm{p}=0.8256$ ). However, there was a significantly higher body height to length ratio for 1995 larvae $(t=-2.04398, \mathrm{p}=0.0425$, Table 5). On the other hand, in both years the body height to length ratio was positively and significantly correlated to length $\left(r^{2}=0.2743, p \ll 0.0001\right.$ for 1994 , and $\mathrm{r}^{2}=0.1762, \mathrm{p} \ll 0.0001$ for 1995) so that a bias due to the higher number of smaller larvae in 1994 must be taken into account.
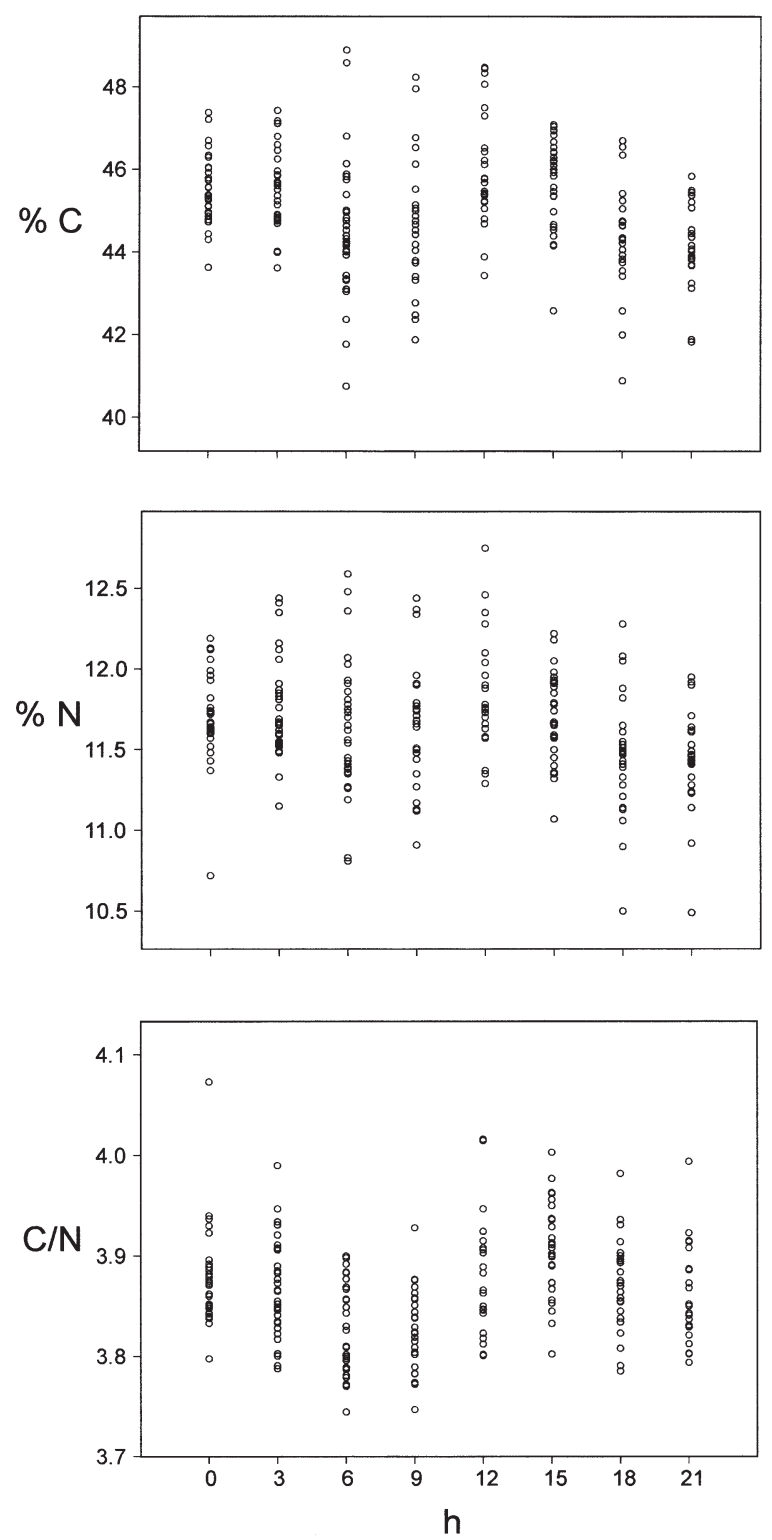

Fig. 6. Micromesistius poutassou. Scatterplots for relationship of time of day to $\mathrm{C}, \mathrm{N}$, and $\mathrm{C} / \mathrm{N}$ ratio 
Table 6. Micromesistius poutassou. Statistics of $\mathrm{C}$ and $\mathrm{N}$ contents (\%) and $\mathrm{C} / \mathrm{N}$ ratio in larvae of the different length classes

\begin{tabular}{|c|c|c|c|c|c|}
\hline Parameter & $3 \mathrm{~mm}$ & $4 \mathrm{~mm}$ & $5 \mathrm{~mm}$ & $6 \mathrm{~mm}$ & $7 \mathrm{~mm}$ \\
\hline \multicolumn{6}{|l|}{ C content } \\
\hline Mean & 45.59 & 45.13 & 44.79 & 43.71 & 43.59 \\
\hline $\mathrm{SD}$ & 1.47 & 1.13 & 1.47 & 1.17 & 2.47 \\
\hline Median & 45.52 & 44.98 & 44.79 & 43.62 & 44.64 \\
\hline Range & $42.00-48.90$ & $42.48-47.96$ & $40.89-48.45$ & $41.88-45.56$ & $40.76-45.36$ \\
\hline \multicolumn{6}{|l|}{$\mathbf{N}$ content } \\
\hline Mean & 11.75 & 11.72 & 11.57 & 11.21 & 11.22 \\
\hline $\mathrm{SD}$ & 0.33 & 0.30 & 0.39 & 0.34 & 0.36 \\
\hline Median & 11.73 & 11.67 & 11.60 & 11.28 & 11.40 \\
\hline Range & $10.90-12.59$ & $11.13-12.46$ & $10.50-12.75$ & $10.49-11.75$ & $10.81-11.45$ \\
\hline \multicolumn{6}{|l|}{$\mathrm{C} / \mathrm{N}$ ratio } \\
\hline Mean & 3.88 & 3.85 & 3.87 & 3.86 & 3.88 \\
\hline SD & 0.05 & 0.05 & 0.06 & 0.06 & 0.10 \\
\hline Median & 3.87 & 3.85 & 3.87 & 3.84 & 3.90 \\
\hline Range & $3.78-4.07$ & $3.74-3.99$ & $3.77-4.00$ & $3.80-3.99$ & $3.77-3.98$ \\
\hline Number of samples & 63 & 89 & 50 & 15 & 3 \\
\hline
\end{tabular}

\section{$\mathrm{C}$ and $\mathrm{N}$ analysis of 1995 blue whiting larvae}

Mean relative carbon $(\mathrm{C})$ content in blue whiting larvae was $45.07 \%(\mathrm{SD}=1.42$, median $=45.05$, range: 40.76 to $48.90, \mathrm{~N}=220$ ) while nitrogen $(\mathrm{N})$ content varied between 10.49 and $12.75 \%$ (mean $=11.66, \mathrm{SD}=$ 0.05 , median $=11.65, \mathrm{~N}=220$ ). The resulting mean $\mathrm{C} / \mathrm{N}$ ratio was $3.86(\mathrm{SD}=0.36$, median $=3.86$, range $=$ 3.74 to $4.07, \mathrm{~N}=220$ ). While the $\mathrm{C} / \mathrm{N}$ ratio remained almost constant with increasing length (Spearman rank-order correlation: $t=0.1786, \mathrm{p}=0.8696$; Table 6), the mean $\mathrm{C}$ and $\mathrm{N}$ contents appeared to decrease significantly (Spearman rank-order correlation: C: $t=\infty$, $\mathrm{p}=0 ; \mathrm{N}: t=-3.5762, \mathrm{p}<0.05$; Table 6).

Both $\mathrm{C}$ and $\mathrm{N}$ content decreased with increasing mean dry wt of the larvae (Fig. 5), while their ratio was not conspicuously affected by dry wt. However, there was a decrease discernible for larvae up to $100 \mu \mathrm{g}$ dry wt. Daytime had an effect on both $\mathrm{C}$ and N. At sunrise, after 03:00 h, carbon content decreased and tended to rise again towards noon. There was a distinct decline in carbon content after 15:00 h (Fig. 6). Nitrogen content remained almost constant between 00:00 and 15:00 h, after which it also dropped conspicuously. The $\mathrm{C} / \mathrm{N}$ ratio (Fig. 6) showed a similar distribution pattern during the day to $\mathrm{C}$ content. Wind stress appeared to have an effect on both $\mathrm{C}$ and $\mathrm{N}$ content, in that both decreased with increasing 6-hourly mean wind speed. The $\mathrm{C} / \mathrm{N}$ ratio appeared to increase slightly up to a wind speed of 6 to $8 \mathrm{~m} \mathrm{~s}^{-1}$, after which it remained almost constant (Fig. 7).

To analyse the combined influence of wind, dry wt and time of day on $\mathrm{C}$ and $\mathrm{N}$ contents of larval blue whiting, we conducted multiple regression analyses. $\mathrm{C}$ and $\mathrm{N}$ data were tested for the underlying distribution.
Both distributions did not differ significantly from a normal distribution (C: K-S test: $\mathrm{d}=0.025$, not significant [ns]; chi-square: $6.62, \mathrm{df}=9, \mathrm{p}=0.677 ; \mathrm{N}$ : K-S test: $\mathrm{d}=0.051, \mathrm{~ns}$; chi-square: 18.84, $\mathrm{df}=12, \mathrm{p}=0.093$ ). Six-hourly wind values and weight data were used as linear continuous variables, whereas time of day was used as a factor. Weight data were $\log _{10}$-transformed prior to analysis. To test the significance of the influence of the covariates, sequential analysis of variance (ANOVA) was carried out.

The resulting regression model for $\mathrm{C}$ was:

$$
\begin{gathered}
C=52.421-0.201 \times \text { wind }-2.645 \times \log _{10}(\text { weight })+T \\
\mathrm{r}^{2}=0.5769, \mathrm{p} \ll 0.0001
\end{gathered}
$$

where $C=$ carbon content in $\%$, wind $=6$-hourly wind speed in $\mathrm{m} \mathrm{s}^{-1}$, weight $=$ mean dry wt in $\mu \mathrm{g}$ and $T=$ the categorical factor for each sampling time (see Table 5). Partial residual analysis revealed that the model sufficiently represented the behaviour of $\mathrm{C}$ in relation to wind, body weight and daytime (Fig. 7) and explained $57.7 \%$ of its variability. All 3 covariates contributed significantly to total C content variability. Sequential

Table 7. Micromesistius poutassou. Categorical factors in C and $\mathrm{N}$ linear models for each sampling time

\begin{tabular}{|lrr|}
\hline Sampling hour & $\mathrm{C}$ & $\mathrm{N}$ \\
\hline $00: 00$ & 0.1365 & -0.0046 \\
$03: 00$ & 0.3091 & 0.0818 \\
$06: 00$ & -0.2394 & 0.0462 \\
$09: 00$ & -0.0546 & 0.0769 \\
$12: 00$ & 0.7112 & 0.1360 \\
$15: 00$ & 0.5961 & 0.0491 \\
$18: 00$ & -0.7210 & -0.2023 \\
$21: 00$ & -0.7379 & -0.1835 \\
\hline
\end{tabular}



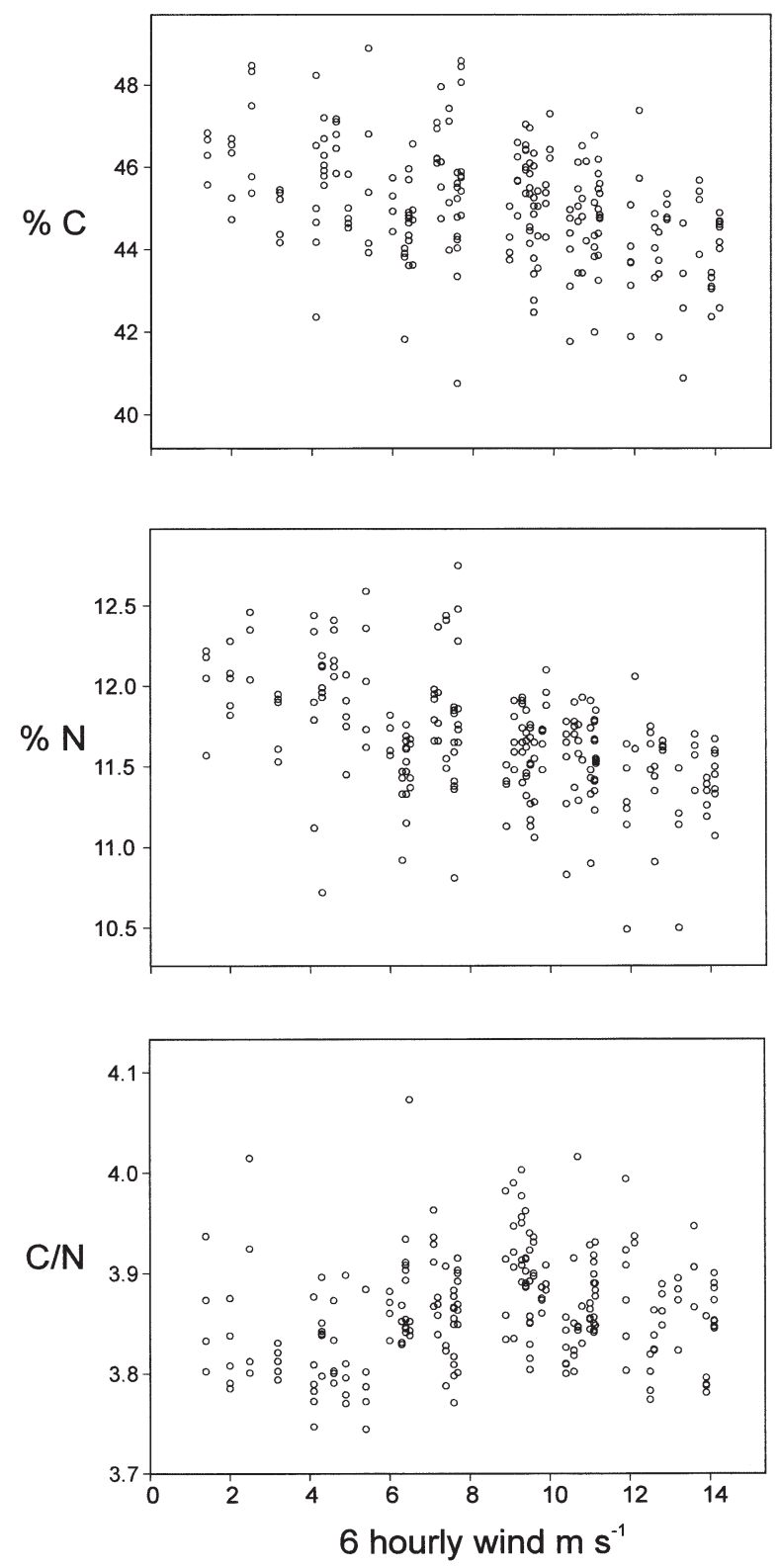

Fig. 7. Micromesistius poutassou. Scatterplots for relationship of wind stress to $\mathrm{C}, \mathrm{N}$, and $\mathrm{C} / \mathrm{N}$ ratio

ANOVA revealed that body weight had the most important influence on C content, explaining $26.8 \%$ of its variability $(F=132.91, \mathrm{p} \ll 0.0001)$, while wind only accounted for $18.1 \%$ variability $(F=90.01, \mathrm{p} \ll 0.0001)$. Daytime had the least influence, explaining only $12.8 \%$ variability $(F=9.06, \mathrm{p} \ll 0.0001)$.

The regression model for $\mathrm{N}$ was:

$$
\begin{gathered}
\mathrm{N}=13.260-0.061 \times \text { wind }-0.496 \times \log _{10}(\text { weight })+T \\
\mathrm{r}^{2}=0.5570, \mathrm{p} \ll 0.0001
\end{gathered}
$$

where $N=$ nitrogen content in $\%$ and all other variables are as explained above. As for $\mathrm{C}$, the residual analysis showed that the model represented the behaviour of $\mathrm{N}$ in relation to wind, body weight and daytime well (Fig. 8) and explained $55.7 \%$ of its variability. However, for the wind parameter, partial residual analysis showed that at wind speeds between 6 and $8 \mathrm{~m} \mathrm{~s}^{-1}$ residuals were not evenly distributed around the regression line but were predominantly below it, indicating that the model overestimates the $\mathrm{N}$ contents at these particular wind speeds. Partially, this finding is explained by the fact that most observations of wind speeds between 6 and $8 \mathrm{~m} \mathrm{~s}^{-1}$ were done at 18:00 and 21:00 $\mathrm{h}$, the time of day when a conspicuous reduction in $\mathrm{N}$ content was found. Again, all 3 parameters contributed significantly to total $\mathrm{N}$ content variability. In contrast to $\mathrm{C}$, wind speed had the most important influence on $\mathrm{N}$ content and accounted for $30.0 \%$ of its variability $(F=141.62, \mathrm{p} \ll 0.0001)$ while only $14.1 \%$ was explained entirely through body weight $(F=53.68$, $\mathrm{p} \ll 0.0001)$. Time of day had the least influence, and accounted for only $11.6 \%$ of total variability $(F=7.82$, $\mathrm{p} \ll 0.0001)$.

\section{DISCUSSION}

In order to judge the impact of wind stress on blue whiting larval condition we carried out 3 different types of condition measurements, 2 of which were morphometric indices (Fulton's $K$ index and body height to standard length ratio) which have latency times of several days (Ferron \& Leggett 1994 and literature therein) and were therefore chosen for betweenyear comparison of contrasting wind stress. The other was carbon and nitrogen content analysis, which is known for its short reaction time $(<12 \mathrm{~h}$ : von Westernhagen et al. 1998) and was therefore chosen for the continuous-drift study. For interpretation of condition results, data on differential feeding success due to wind stress were utilised.

\section{Morphological condition indices}

Though there was a significant difference in feeding success between years (see above), the morphometric condition measurements revealed somewhat contradictory differences in the nutritional state of the larvae. Fulton's condition index was significantly lower for blue whiting larvae in 1994 than in 1995 because isometric growth of the 1994 larvae was restricted. The dry wt measurements indicated that approximately $11 \%$ of the larvae showed serious signs of malnutrition. Within the same year, these larvae were significantly lighter than their conspecifics at similar lengths. However, these results were not corroborated by the 

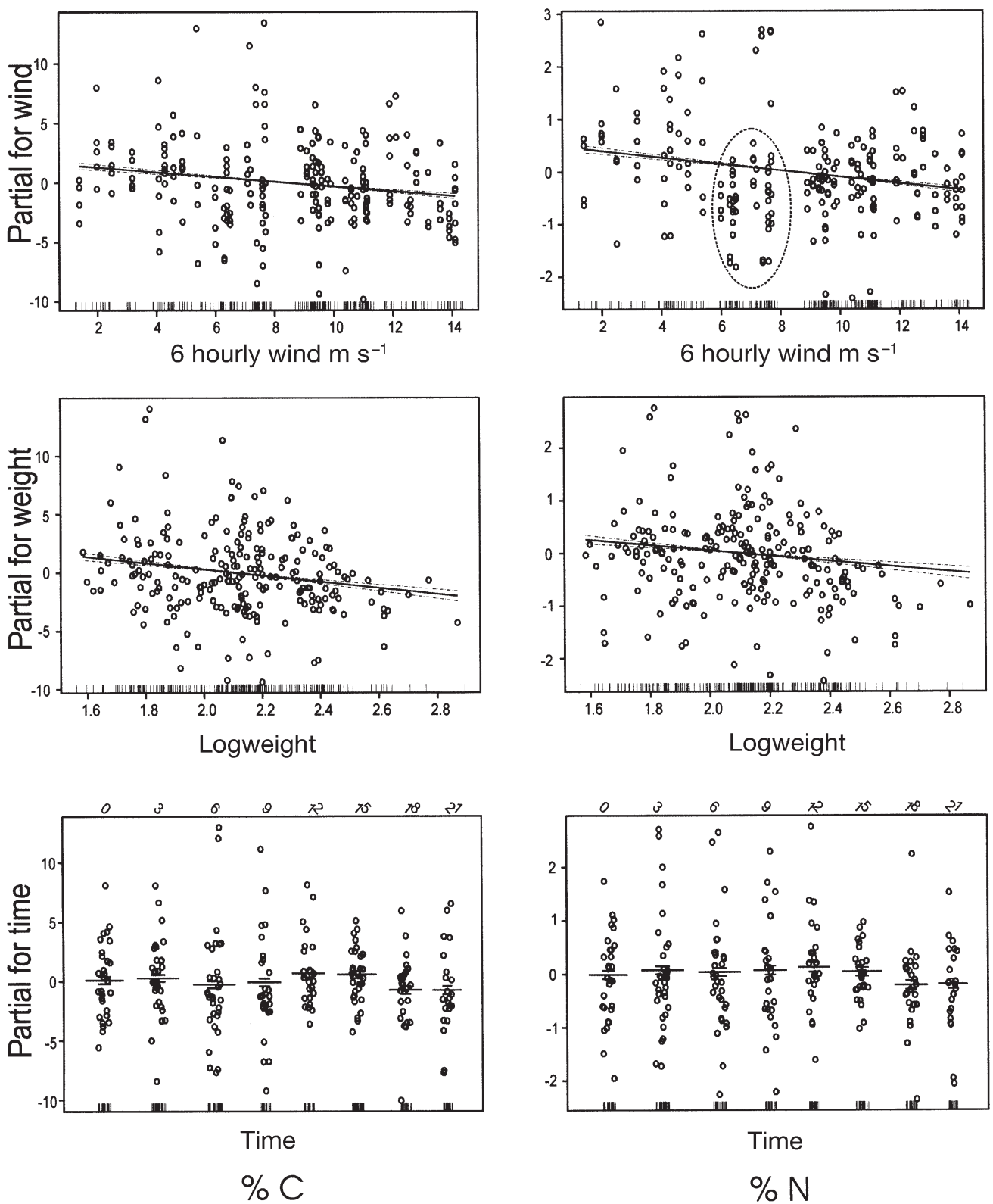

Fig. 8. Micromesistius poutassou. Partial residuals for $\mathrm{C}$ and $\mathrm{N}$ relationships to wind stress, weight and time of day. Whiskers on abscissa represent data density for a given interval of predictor values

standard length/body height ratio, which only showed slight and probably biased differences between both years. These somewhat contradictory results may have been caused by different latency times for both condition factors examined. During starvation, fish larvae are able to utilise energy by metabolising protein from muscle tissue (Love 1970), which is replaced by an increase in intercellular space and cellular water content, resulting in a reduced body dry wt but presumably not body height. Only after prolonged starvation, due to a breakdown of the osmoregulatory system, do fish larvae lose water to the environment (Sclafani et al. 1997) and become thinner. As a consequence, larvae become less buoyant and sink. Larvae examined for condition in the present study were all captured in the top 50 (1994) to $60 \mathrm{~m}$ (1995) of the water column. Larvae in poor condition with respect to body height might have sunk below the investigated depth strata, thus reducing the probability of capturing them within the top 50 to $60 \mathrm{~m}$. This fact may explain the apparent contradictory results between morphometric condition factors, suggesting that in 1994 the proportion of malnourished larvae may have been even larger than the observed $11 \%$. 


\section{Carbon and nitrogen contents}

Multiple regression analysis indicated that relative $\mathrm{C}$ content, a measure that has previously been postulated as an indicator for larval condition (Coombs et al. 1999), was primarily and negatively influenced by body weight. This appears contradictory to most other studies on $\mathrm{C}$ content in fish larvae in which it was observed to increase with growth (Ehrlich 1974a, Harris et al. 1986, Ikeda 1996, Coombs et al. 1999). However, Ehrlich (1974b) found that a constant increase in relative $\mathrm{C}$ content with growth is not the rule. Also, absolute $\mathrm{C}$ and $\mathrm{N}$ contents for growing Blennius pavo larvae indicated a possible decrease in relative $\mathrm{C}$ and N content with age (Freitas 1993). Indeed, fishes do show quite different behaviour in energy deposition with respect to lipid content (Anthony et al. 2000). Thus, a decrease in relative $\mathrm{C}$ content of fish larvae with age may not be a sign of deteriorating condition, but reflects a species-specific behaviour of energy storage.

Approximately $18 \%$ of the total $\mathrm{C}$ content variability was explained by wind stress, indicating that turbulence has a slight but significant negative effect on C deposition. This might be the result of reduced feeding intensity with increasing wind speed (Hillgruber \& Kloppmann 2000) and, thus, an increased utilisation of reserve carbohydrates. The fact that the time of day to C content relationship significantly reflected the daily feeding rhythm of blue whiting larvae, as described by Hillgruber \& Kloppmann (2000), suggests that gut contents might influence relative $\mathrm{C}$ content (Lochmann et al. 1996). However, C content in early developmental stages of copepods (the primary prey of blue whiting larvae: Hillgruber \& Kloppmann 1999, 2000) at that particular time of year is lower $(<40 \%$, Bottrell \& Robins 1984) than that of blue whiting larvae (about

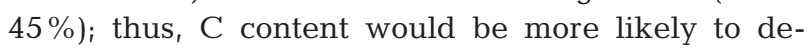
crease with increasing feeding intensity.

In contrast to larval $\mathrm{C}$ content, relative $\mathrm{N}$ content was predominantly and significantly influenced by wind speed. This was not due to the reduction in feeding intensity with increasing wind stress (Hillgruber \& Kloppmann 2000), since time of day contributed less to the variability of $\mathrm{N}$ content than to $\mathrm{C}$ content and appeared to be more constant during the day, with the only significant reduction occurring in the late evening hours. Furthermore, with a relative $\mathrm{N}$ content of 8 to $9 \%$ in early developmental stages of copepods (Bottrell \& Robins 1984) the N content of blue whiting larvae (about $11 \% \mathrm{~N}$ ) is more likely to increase with reduced feeding success if gut contents have a significant influence.

Proteins are considered to be the primary energy resource for fish larvae (Ehrlich 1974a,b, Klumpp \&
Westernhagen 1986, Torres et al. 1996), supplying the majority of material for the assimilation of new body tissue during growth. Since $\mathrm{N}$ is predominantly found in proteins, the relative $\mathrm{N}$ content of fish larvae may give insight into the rate of ingested protein retained for growth (Linton et al. 1998). N retention is depressed during critical periods of increased physiological stress, e.g. during transition from endogenous to exogenous feeding or during metamorphosis, when more protein is utilised for energy expenditure (Yúfera et al. 1993, Christensen \& Korsgaard 1999, Yúfera et al. 2000). Similarly, wind stress might also increase energy demands on a fish larva since more resources are needed for behaviour such as maintaining a preferred depth (Hillgruber \& Kloppmann 2000) or successfully capturing prey organisms (MacKenzie \& Kiørboe 2000). As a consequence, more protein will be catabolised, leaving less for assimilation into new body tissue. This might explain the decline in $\mathrm{N}$ content with increasing wind stress.

Thus, while $\mathrm{C}$ content in blue whiting larvae may be primarily explained by changing energy storage mechanisms characteristic for a developing larva and be only partially due to differential feeding success, $\mathrm{N}$ content clearly reflects changes in nutritional condition imposed by external stress such as intensive windmixing. It appears that gross growth efficiency in blue whiting larvae is maximised during calm wind situations.

\section{Feeding and wind stress}

Increased wind stress can significantly reduce feeding success in larval blue whiting despite the persistence of sufficiently large prey patches (Hillgruber \& Kloppmann 2000). However, fish larvae are probably able to survive short periods of high wind stress, if these do not affect the prey environment, and to recover from such reductions in condition and growth (e.g. Dabrowski et al. 1986). Problems may only arise if high wind stress persists over a longer time period and prey abundance and production are continuously affected. Especially at the time of year of our study, strong and unidirectional wind stress may have affected the timing of the spring bloom and may also have resulted in expatriation of the copepod spawning stock (Lewis et al.1994), both having led to reduced naupliar production and, hence, the observed reduced abundance of food in 1994. Furthermore, strong windmixing in 1994 would have destroyed or prevented any concentration of prey items, as has been previously shown for other areas (Lagadeuc et al. 1997, Conway et al. 1998). In 1995 the comparatively low and directionally variable wind stress resulted in higher nau- 
pliar production and the formation of layers of high prey densities at $30 \mathrm{~m}$ depth.

The considerable difference in feeding intensity, both in numbers of prey items and in weight of gut contents (Fig. 2), clearly shows that blue whiting larvae benefited from higher prey densities in April 1995. While the analysis of larval dry wt revealed that in both years of our study a high proportion of blue whiting larvae were probably not starving, the FCI analysis indicated that certain larvae did not grow isometrically, suggesting that a proportion of the larval population was affected by the low prey density in 1994. This has already been shown for larval walleye pollock Theragra chalcogramma for contrasting years of wind stress and prey abundance (Bailey et al. 1995). Mortality of pollock larvae almost doubled in the year of higher wind stress and lower food abundance. Bailey et al. concluded that the prey levels in the year of high wind-mixing were too low for the larvae to benefit from the increased turbulence. However, in laboratory observations, cod Gadus morhua larvae were observed to cope with low prey densities $(<10$ nauplii $\mathrm{l}^{-1}$ ) particularly well by adjusting their prey-search and prey-selection behaviour (Munk 1995). Similar results were obtained in a study on the walleye pollock, whereby prey concentrations of as low as 8 nauplii $1^{-1}$ still provided a sufficiently dense prey environment for initiation of feeding (Paul 1983). Even at densities of 2 nauplii $l^{-1}, 2 \%$ of the larvae were feeding, suggesting that within any larval population individual variation in prey-capture success is considerable and highly dependent on prey concentration. Switching to larger food items such as calanoid nauplii and copepodites (Tables 3 \& 4) might, at some stage, have helped blue whiting larvae to compensate for the lower naupliar prey abundance in 1994. Larval blue whiting, like other gadoid larvae, might therefore be considered as 'prey-insensitive' larvae (Houde 1987) which have adapted to food-limiting situations, since they normally hatch prior to the seasonal copepod peak into a comparatively poor prey environment (Hillgruber \& Kloppmann 1997, Hillgruber et al. 1999).

However, while starvation might not be the sole source of larval mortality, small declines in growth rates due to lower than optimum food levels might prolong the larval stage duration over which high mortality rates can operate (Houde 1987). While no information on larval growth rates are available for 1994, there is an indication of such a process operating in 1994, when a proportion $(11 \%)$ of blue whiting larvae exhibited significantly lower growth in weight between 4.0 and $6.0 \mathrm{~mm}$ than larvae in 1995. Furthermore, it was evident that isometric growth was already restricted in at least some of the 1994 larvae, i.e. the larvae were already losing weight relative to their size. However, growth can be inhibited long before weight-at-length is affected (see e.g. Bailey \& Heath 2001); therefore, these larvae might have already shown reduced growth rates for quite some time. Thus, the low feeding intensities, particularly of larvae $>3.5 \mathrm{~mm}$, suggest that in $1994 \mathrm{a}$ considerable proportion of blue whiting larvae was growth-limited. Because $\mathrm{C}$ and $\mathrm{N}$ analysis clearly demonstrated a decreased $\mathrm{N}$ assimilation efficiency at high wind stress, we conclude that it was more likely the combination of increased wind stress and low prey abundance than the poor prey levels alone that had a detrimental effect on condition, growth, and, hence, survival of blue whiting larvae in 1994.

In summary, it is evident that prolonged high wind stress affects blue whiting larval biology in multiple ways. It increases the energy demands in blue whiting larvae, which immediately has an effect on growth as indicated by a reduction in $\mathrm{N}$ retention under high wind stress. It disperses existing prey patches and prevents restoration of these, while it also reduces larval feeding success (MacKenzie \& Kiørboe 2000). The current study supports the conclusion that the unusually calm wind situation in 1995 resulted in higher prey concentration, and consequently better feeding success and condition of larval blue whiting and, thus, most probably in higher larval survival rates. Therefore, one of the reasons for the success of the 1995 blue whiting year-class may have been the favourable wind conditions during the larval phase; however, in order to have a bearing on recruitment, conditions during the juvenile phase must have been favourable also.

Acknowledgements. This study was financially supported as part of the EU/AIR Grant No AIR2-CT93-1105. Nicole Laude carried out $\mathrm{C}$ and $\mathrm{N}$ analysis on blue whiting larvae, and Nils Peters measured and weighed the larvae for morphological condition indices. We are deeply indebted to Dr. Sara Adlerstein, Institute of Hydrobiology and Fisheries Science, Hamburg, for helping with multiple regression analysis and an introduction into S-Plus software. Three anonymous referees provided valuable suggestions for improvement of the manuscript. This article is based in part on a doctoral study by N.H. in the Faculty of Biology, University of Hamburg. N.H. was supported by a graduate scholarship provided by the Biologische Anstalt Helgoland, Hamburg, Germany.

\section{LITERATURE CITED}

Anonymous (1996) Report of the northern pelagic and blue whiting fisheries working group. Int Counc Explor Sea Counc Meet 1996/Assess 14

Anthony JA, Roby DD, Turco KR (2000) Lipid content and energy density of forage fishes from the northern Gulf of Alaska. J Exp Mar Biol Ecol 248:53-78

Bailey KM, Macklin SA (1994) Analysis of patterns in larval walleye pollock Theragra chalcogramma survival and wind-mixing events in Shelikof Strait, Gulf of Alaska. Mar Ecol Prog Ser 113:1-12 
Bailey KM, Canino MF, Napp JM, Spring SM, Brown AL (1995) Contrasting years of prey levels, feeding conditions and mortality of larval walleye pollock Theragra chalcogramma in the western Gulf of Alaska. Mar Ecol Prog Ser 119:11-23

Bailey MC, Heath MR (2001) Spatial variability in the growth rate of blue whiting (Micromesistius poutassou) larvae at the shelf edge west of the UK. Fish Res 57:73-87

Bailey RS (1992) The population biology of blue whiting in the North Atlantic. Adv Mar Biol 19:257-355

Bartsch J, Coombs S (1997) A numerical model of the dispersion of blue whiting larvae, Micromesistius poutassou (Risso), in the eastern North Atlantic. Fish Oceanogr 6: 141-154

Bottrell HH, Robins DB (1984) Seasonal variations in length, dry wt, carbon and nitrogen of Calanus helgolandicus from the Celtic Sea. Mar Ecol Prog Ser 14:259-268

Chambers JM, Hastie TJ (1992) Statistical models. Wadsworth \& Brooks/Cole, South Pacific Grove, CA

Christensen MN, Korsgaard B (1999) Protein metabolism, growth and pigmentation patterns during metamorphosis of plaice (Pleuronectes platessa) larvae. J Exp Mar Biol Ecol 237:225-241

Conway DVP (1980) The food of larval blue whiting, Micromesistius poutassou (Risso), in the Rockall area. J Fish Biol 16:709-723

Conway DVP, Coombs SH, Smith C (1998) Feeding of anchovy Engraulis encrasicolus larvae in the northwestern Adriatic Sea in response to changing hydrobiological conditions. Mar Ecol Prog Ser 175:35-49

Coombs SH, Conway DVP, Morley SA, Halliday NC (1999) Carbon content and nutritional condition of sardine larvae (Sardina pilchardus) off the Atlantic coast of Spain. Mar Biol 134:367-373

Cury P, Roy C (1989) Optimal environmental window and pelagic fish recruitment success in upwelling areas. Can J Fish Aquat Sci 46:670-680

Cushing DH (1990) Plankton production and year-class strength in fish populations: an update of the match/ mismatch hypothesis. Adv Mar Biol 26:249-293

Dabrowski K, Takashima F, Strüssmann C (1986) Does recovery growth occurs (sic) in larval fish? Bull Jpn Soc Sci Fish 52:1869

DHI (Deutsches Hydrographisches Institut) (1967) Monatskarten für den Nordostatlantischen Ozean, 4. Auflage, Nr. 2420, Atlas. Deutsches Hydrographisches Institut, Hamburg

Dower JF, Miller TJ, Leggett WC (1997) The role of microscale turbulence in the feeding ecology of larval fish. Adv Mar Biol 31:170-220

Ehrlich KF (1974a) Chemical changes during growth and starvation of herring larvae. In: Blaxter JHS (ed) The early life history of fish. Springer-Verlag, Berlin, p 301-323

Ehrlich KF (1974b) Chemical changes during growth and starvation of larval Pleuronectes platessa. Mar Biol 24: 39-48

Ferron A, Leggett WC (1994) An appraisal of condition measures for marine fish larvae. Adv Mar Biol 30:217-303

Fiksen Ø, Utne ACW, Aksnes DL, Eiane K, Helvik JV, Sundby S (1998) Modelling the influence of light, turbulence and ontogeny on ingestion rates in larval cod and herring. Fish Oceanogr 7:355-363

Frank KT, McRuer JK (1989) Nutritional status of fieldcollected haddock (Melanogrammus aeglefinus) larvae from southwestern Nova Scotia: an assessment based on morphometric and vertical distribution data. Can J Fish Aquat Sci 46 (Suppl 1):125-133
Freitas C (1993) Der Gehalt von Kohlenstoff (C) und Stickstoff $(\mathrm{N})$ in Fischeiern und -larven verschiedenen Entwicklungsalters und unterschiedlicher Ernährungszustände. Diploma thesis, University of Hamburg

Harris RK, Nishiyama T, Paul AJ (1986) Carbon, nitrogen and caloric content of eggs, larvae, and juveniles of the walleye pollock, Theragra chalcogramma. J Fish Biol 29:87-98

Hillgruber N, Kloppmann M (1999) Distribution and feeding of blue whiting Micromesistius poutassou larvae in relation to different water masses in the Porcupine Bank area, west of Ireland. Mar Ecol Prog Ser 187:213-225

Hillgruber N, Kloppmann M (2000) Vertical distribution and feeding of larval blue whiting, Micromesistius poutassou, in turbulent waters above Porcupine Bank. J Fish Biol 57: $1290-1311$

Hillgruber N, Kloppmann M, Wahl E, von Westernhagen H (1997) Feeding of larval blue whiting and Atlantic mackerel: a comparison of foraging strategies. J Fish Biol 51 (Suppl A):230-249

Houde ED (1987) Fish early life dynamics and recruitment variability. Am Fish Soc Symp 2:17-29

Ikeda T (1996) Metabolism, body composition, and energy budget of the mesopelagic fish Maurolicus muelleri in the Sea of Japan. Fish Bull 94:59-58

Isaev NA, Seliverstov AS (1991) Population structure of the Hebridean-Norwegian school of blue whiting Micromesistius poutassou. J Ichthyol 31:45-58

Kiørboe T, Saiz E (1995) Planktivorous feeding in calm and turbulent environments with emphasis on copepods. Mar Ecol Prog Ser 122:135-145

Kloppmann M, Mohn C, Bartsch J (2001) The distribution of blue whiting eggs and larvae on Porcupine Bank in relation to hydrography and currents. Fish Res 50:89-109

Klumpp DW, von Westernhagen H (1986) Nitrogen balance in marine fish larvae: influence of developmental stage and prey density. Mar Biol 93:189-199

Koslow JA, Brault S, Dugas J, Fournier RO, Hughes P (1985) Condition of larval cod (Gadus morhua) off southwest Nova Scotia in 1983 in relation to plankton abundance and temperature. Mar Biol 86:113-121

Lagadeuc Y, Boulé M, Dodson JJ (1997) Effect of vertical mixing on the vertical distribution of copepods in coastal waters. J Plankton Res 19:1183-1204

Lasker R (1975) Field criteria for survival of anchovy larvae: the relation between inshore chlorophyll maximum layers and successful first feeding. Fish Bull 73:453-462

Leising AW, Franks PJS (1999) Larval Atlantic cod (Gadus morhua) and haddock (Melanogrammus aegelfinus) growth on Georges Bank: a model with temperature, prey size, and turbulent forcing. Can J Fish Aquat Sci 56:25-36

Lewis CVW, Cabell SD, Gawarkiewcz G (1994) Wind forced biological-physical interactions on an isolated offshore bank. Deep-Sea Res Part II 41:51-73

Linton TK, Reid SD, Wood CM (1998) The metabolic costs and physiological consequences to juvenile rainbow trout of a simulated winter warming scenario in the presence or absence of sublethal ammonia. Trans Am Fish Soc 127: 611-619

Lochmann SE, Maillet GL, Taggart CT, Frank KT (1996) Effect of gut contents and lipid degradation on condition measures in larval fish. Mar Ecol Prog Ser 134:27-35

Love RM (1970) The chemical biology of fishes, Vol 1. Academic Press, New York

MacKenzie BR, Kiørboe T (2000) Larval fish feeding and turbulence: a case for the downside. Limnol Oceanogr 45:1-10

MacKenzie BR, Miller TJ, Cyr S, Leggett WC (1994) Evidence 
of a dome-shaped relationship between turbulence and larval fish ingestion rate. Limnol Oceanogr 39:1790-1799 MathSoft (1999) S-Plus 2000. MathSoft, Seattle, WA

Munk P (1995) Foraging behaviour of larval cod (Gadus morhua) influenced by prey density and hunger. Mar Biol 122:205-212

Paul AJ (1983) Light, temperature, nauplii concentration, and prey capture by first feeding pollock larvae Theragra chalcogramma. Mar Ecol Prog Ser 13:175-179

Rothschild BJ, Osborn TR (1988) Small-scale turbulence and plankton contact rates. J Plankton Res 10:465-474

Sclafani M, Stirling G, Leggett WC (1997) Osmoregulation, nutritional effects and buoyancy of marine larval fish: a bioassay for assessing density changes during the earliest life-history stages. Mar Biol 129:1-9

SEFOS (Shelf Edge Fisheries and Oceanography Study) (1997) Official final report. Contract No. CT93-1105. European Commission, DG XIV, Brussels

Sundby S (1995) Wind climate and foraging of larval and juvenile Arcto-Norwegian cod (Gadus morhua). In: Beamish RJ (ed) Climate change and northern fish populations. Can Spec Publ Fish Aquat Sci 121:405-415

Sundby S, Fossum P (1990) Feeding conditions of ArctoNorwegian cod larvae compared with the Rothschild-

Editorial responsibility: Otto Kinne (Editor),

Oldendorf/Luhe, Germany
Osborn theory on small-scale turbulence and plankton contact rates. J Plankton Res 12:1153-1162

Suthers IM, Fraser A, Frank KT (1992) Comparison of lipid, otolith and morphometric condition indices of pelagic juvenile cod Gadus morhua from the Canadian Atlantic. Mar Ecol Prog Ser 84:31-40

Torres JJ, Brightman RI, Donnelly J, Harvey J (1996) Energetics of larval red drum, Sciaenops ocellatus. Part I. Oxygen consumption, specific dynamic action, and nitrogen excretion. Fish Bull 94:756-765

von Westernhagen H, Freitas C, Fürstenberg G, Willführ-Nast $\mathrm{J}$ (1998) C/N data as an indicator of condition in marine fish larvae. Arch Fish Mar Res 46:165-179

White M, Mohn C, Orren MJ (1998) Nutrient distribution across the Porcupine Bank. ICES J Mar Sci 55:1082-1094

Yúfera M, Polo A, Pasqual E (1993) Changes in the chemical composition and biomass during the transition from endogenous to exogenous feeding of Sparus aurata L. (Pisces, Sparidae) larvae reared in the laboratory. J Exp Mar Biol Ecol 167:149-161

Yúfera M, Parra G, Santiago R, Carrascosa M (2000) Growth, carbon, nitrogen and caloric content of Solea senegalensis (Pisces: Soleidae) from egg fertilization to metamorphosis. Mar Biol 134:43-49

Submitted: March 29, 2001; Accepted: December 13, 2001 Proofs received from author(s): May 10, 2002 